\title{
Factories: Getting Rid Of Learning
}

Allen Jackson, Northcentral University and Chadron State College, USA

Laura Gaudet, Chadron State College, USA

\begin{abstract}
The No Child Left Behind (NCLB) Act has been the main focus of educational debate since we entered the $21^{\text {st }}$ Century. It has left educators in dispute about the reasonableness of federallyordered reforms and the necessity for holding all students to the same academic standards. The 2001 legislation expanded the federal government's role in public education and required greater school accountability and teacher qualifications with little concern for mandate funding. The $N C L B$ requirements have resulted in larger public schools and rural school consolidation. This development has placed unnecessary burden on public schools and has forced many districts to eliminate educational programming. This article will discuss the ramifications of NCLB in public school settings, as well as the specific problems of schools in rural areas.
\end{abstract}

Keywords: No Child Left Behind (NCLB), School Reform, Elementary and Secondary Education Act of 1994, School Consolidation

\section{INTRODUCTION}

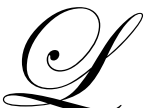

eave no child behind," powerful in its simplicity, daunting in its complexity; this is the challenge posed by the President of the United States and the Congress in reauthorizing the Elementary and Secondary Education Act" (Wenning, Herdman, \& Smith, n.d., p. 1). The No Child Left Behind Act (NCLB) has been the main focus of educational dispute since we entered into the $21^{\text {st }}$ Century. Was it initiated with good intent or merely a quest to gain popularity with the American public?

Since its conception in 2001, NCLB, an act of federal reform, originally designed at raising expectations of public schooling in America, has left our Nation's educators stalled in debate about the reasonability of these federally-ordered reforms. How much public understanding is there about the expectations of NCLB and are these forthcoming demands reasonable when we consider the global climate of educational needs for students of the next millennium (Richmond, 1994)? Albert Shanker, President of the American Federation of Teachers, stated "It's time to admit that public education operates like a planned economy, a bureaucratic system in which everybody's role is spelled out in advance and there are few incentives for innovation and productivity" (Richmond, 1994, p. 1).

NCLB continued the emphasis established in the previous reauthorization of the Elementary and Secondary Education Act of 1994 by holding all students to the same academic standards (Reeves, 2003). When we take into account the growth and expansion of technology along with Third World acquisition of mass production and industrialization, is it realistic to consider issues of educational reform from1994 as relevant to the needs of today's students? This 2001 legislation expanded the federal role in public education by requiring stronger school accountability, more stringent qualifications for teachers, and an emphasis on programs and strategies with little consideration about funding such mandates. Yet, demands continue to come from our federal government in an attempt to initiate change.

NCLB was designed to ensure that all students make adequate yearly progress toward achieving a designated level of competence in accordance with state standards (Reeves, 2003). Academic competence would be realized through the development of standardized testing to measure student achievement. These testing demands, to decide the value of the educational process, does very little to actually improve student learning (Winter, 2002).

Our federal government's idea of standardized testing is related to the concept of tying test scores to schools accountability. Thus, student learning will be taken seriously, resulting in higher teaching performance and 
greater student achievement (Winter, 2002). This creates a climate within our public schools where there is so much emphasis on academic excellence that the true meaning of a free and equal education for all children is often ignored. With calls of accountability, many schools have been challenged to change curricular programming in an attempt to meet governmental criterion for excellence.

The requirements of NCLB, without accompanying funds to implement federal mandates, result in a nationwide push for larger schools especially in the rural areas of our country. The drive toward school consolidation in rural areas is directly related to the lack of resources required to sustain smaller school districts. As the goal of NCLB, with federally proclaimed improvement in academic achievement for all students, our federal government has been blinded by the call for reform. NCLB requirements, combined with funding inequities and other economic issues, have placed unnecessary pressure on public schools and are forcing many districts to eliminate educational programs from their curriculum. In many areas of our country, the only recourse for school districts is to consolidate or close district doors. Many smaller schools have been targeted for consolidation due to the perception that, through consolidation, funding for education will be better used and students will be better served. In contrast, educational research points toward smaller schools in regard to learning efficiency (Reeves, 2003). With reform measures in place, education in American schools have come under intense scrutiny, with expectations for improved student achievement and school accountability as the center of focus.

Are these attempts at reform truly good for the sanctity of our educational system or are government mandates interfering with the integrity of an otherwise sound system? Local school districts will, most assuredly, respond to the demands and needs of the communities they serve. As a country, do we have so little faith in an educational system built around the needs of our people that we ignore the fact that this same system, we are so anxious to change, has meet every challenge it has faced in the preparation of our youth? Are we wasting what little federal funding we receive to comply with federal demands with little regard for what is truly needed? Our educational system should allow for personal discovery. It should challenge creativity and foster an environment where students are encouraged to use their minds to solve problems, not just those carefully worked out by an assessment system which leaves little to the imagination.

\section{CONCLUSION}

If left unchecked, the demands of our federal government will create an educational system much like the society created by the industrial revolution. This will be a system based on mass production of our most valuable commodity imaginable, our Nation's youth. When we consider our country, with its diverse accumulation of ethnicity, cultures, religions, and beliefs, it is hard to understand an educational system that strives to develop generations of students educated with common standards dictated by our federal and state governments. Is it safe to believe that reforms imposed on our educational system, by the 2002 Bush administration, will actually result in no child being left behind?

\section{AUTHOR INFORMATION}

Allen Jackson, M. Ed. is an Assistant Professor at Chadron State College, in Chadron, Nebraska. He has taught in the Department of Health, Physical Education and Recreation (HPER) for five years. He teaches course in Personal Health and Wellness, Introduction to Recreation, Biomechanics of Sports, Community and Environmental Health and several activities courses. He is a doctoral student at Northcentral University in Prescott Valley, Arizona and is about to begin the dissertation phase of his program.

Laura Gaudet, Ph. D. is a Professor of Psychology at Chadron State College, in Chadron, Nebraska. She has taught in the Department of Counseling, Psychology, and Social Work for ten years and has served as the Chairperson of the department since 2003. As she has degrees in both Psychology and Counseling, she teaches both undergraduate Psychology and graduate Counseling courses in Multicultural Counseling, Consultation \& Program Development, School Counseling, Family Counseling, Advanced Developmental Psychology, Career and Lifestyle Development, Ethical and Legal Issues, Child Psychology, Developmental Psychology, Abnormal Psychology, and General Psychology. She primarily develops and teaches courses online. 


\section{REFERENCES}

1. Reeves, C. (2003). Implementing the No Child Left Behind Act: Implications for rural schools and districts (Institute of Educational Sciences (IES), U.S. Department of education, ED-01-CO-0011). Naperville, IL: North Central Regional Educational Laboratory.

2. Richmond, S. (2005, March). What's wrong with public schools? In Separating school \& state: How to liberate America's families. (chap. 2). Retrieved January 22, 2006, from http://www.fff.org/comment/com0503m.asp

3. Wenning, R.J., Herdman, P.A., \& Smith, N. (n.d.). No Child Left Behind: Who is included in new federal accountability requirements? Paper prepared for Will No Child Truly Be Left Behind? The Challenges of Making This Law Work Conference, sponsored by the Thomas B. Fordham Foundation. Retrieved January 21, 2006, from http://www.naschools.org/uploadedfiles/NCLB\%20Act\%20pdf.pdf

4. Winter, G. (2002, December 28). More schools rely on tests, but study raises doubts. New York Times. Retrieved January 21, 2006, from http://www.ccebso.org/timestestingdoubts.html 
NOTES 